\title{
Genetic Relationships of Codiaeum variegatum Cultivars Analyzed by Amplified Fragment Length Polymorphism Markers
}

\author{
Min Deng ${ }^{1}$, Jianjun Chen ${ }^{2}$, Richard J. Henny, and Qiansheng $\mathbf{L i}^{1}$ \\ University of Florida, Institute of Food and Agricultural Sciences, \\ Department of Environmental Horticulture and Mid-Florida Research and \\ Education Center, 2725 Binion Road, Apopka, FL 32703-8504
}

Additional index words. AFLP analysis, crotons, tropical ornamental foliage plants

\begin{abstract}
Codiaeum variegatum (L.) Blume, commonly known as crotons, are among the most popular ornamental foliage plants cultivated for either landscaping or interiorscaping. Currently, more than 300 cultivars are available; each has a distinct phenotype, particularly in leaf morphology. Thus far, there is no information regarding their genetic relationships. In this study, genetic relatedness of 44 cultivars of $C$. variegatum was investigated using amplified fragment length polymorphism (AFLP) markers. Fourteen primer combinations generated a total of 549 AFLP fragments, which were used to estimate genetic distances and construct dendrograms based on the neighbor-joining method. The 44 cultivars were divided into seven clusters, which concurred with the known history of croton geographical isolation, adaptation, introduction, and breeding activities but differed from the classification made by the Croton Society based on leaf morphology. The established genetic relationships could be important for future germplasm identification and conservation and new cultivar development. Additionally, genetic distance among the 44 cultivars was 0.322 or less, indicating that they have a narrow genetic base. The narrow genetic base may indicate that the cultivars were derived from a common progenitor. On the other hand, $81 \%$ of the 549 fragments were polymorphic and the average polymorphic information content was 0.22 , which suggests that the cultivars are genetically highly polymorphic. The high polymorphisms may be attributed to significant gene loss or gain facilitated by mutation and/or chromosome variation, thus contributing to a wide range of leaf morphological differences among cultivars.
\end{abstract}

The genus Codiaeum A. Juss. belongs to the family Euphorbiaceae and encompasses 17 species native to tropical forests from Indonesia and the Philippines to New Guinea and Australia (Govaerts et al., 2000). Codiaeum variegatum (L.) Blume, commonly referred to as crotons, are small evergreen trees and shrubs with varied leaf shapes and vivid foliage colors displayed as shades, blends, combinations, or solid patches of red, pink, orange, yellow, lavender, black, and green. Leaf sizes range from small $(6 \mathrm{~cm}$ long $\times$ $1 \mathrm{~cm}$ wide $)$ to large $(35 \mathrm{~cm}$ long $\times 13 \mathrm{~cm}$ wide), and margins can be entire or trifurcate. Leaf shapes vary from simple ovate to linear; some are slightly or deeply cut, and others are

Received for publication 5 Mar. 2010. Accepted for publication 19 Apr. 2010.

We thank Green Terra, Inc., Coral Springs, FL, and Hermann Engelmann Greenhouses, Inc., Apopka, FL, for providing plant materials used in this study and Russell D. Caldwell for assistance in plant collection and for critical review of the manuscript. ${ }^{1}$ Current address: School of Ecological Technology and Engineering, Shanghai Institute of Technology, Shanghai, China.

${ }^{2}$ To whom reprint requests should be addressed; e-mail jjchen@ufl.edu. connected with the blade only by the midrib. Thus, crotons are valued mainly for their attractive foliage. Currently, more than 300 cultivars are reported in the world, and they are cultivated as either landscape plants or containerized foliage plants (Chen et al., 2005).

Native to the Mollucan Islands of Indonesia (Brown, 1995), crotons were first introduced to England in 1804, but hybrids were developed mainly in Belgium and France in the 1800s. Many of the European hybrids were introduced into the United States in 1871. At least 70 hybrids, commonly known as Florida hybrids, were developed in south Florida during the 1920s and 1930s. Crotons are monoecious with poor seed set, and seed propagation results in plants with different phenotypes (Sharma and Bal, 1958). In commercial production, once a hybrid selection is made, it is propagated asexually through stem cuttings (Chen and Stamps, 2006).

The Croton Society (2010) categorizes croton cultivars into nine types based on their leaf morphology: 1) broad leaf; 2) oak leaf; 3 ) semioak leaf; 4) spiral leaf; 5) narrow leaf; 6) very narrow leaf; 7) small leaf; 8) interrupted leaf; and 9) recurved leaf. However, information regarding the genetic relationships of cultivated crotons is incomplete. Cytological studies of cultivars produced in India (Sharma and Bal, 1958), the Philippines (Pancho and Hilario, 1963), Nigeria (Ogunwenmo et al., 2007), and Florida (Deng et al., 2010) showed that crotons are predominantly polyploid with $2 n=60$ to 120 . Endoreduplication, irregular chromosome segregation, spindle multipolarity, and unusual nucleus shape were observed in crotons and proposed to be the mechanisms underlying the wide range of chromosome variation (Chennaveeraiah and Wagley, 1985). As a result, genetic relationships among cultivars have not been established (Deng et al., 2010; Sharma and Bal., 1958), which has hampered our efforts on croton germplasm conservation and new cultivar development.

Amplified fragment length polymorphism (AFLP), a polymerase chain reaction-based technique for DNA fingerprinting (Vos et al., 1995), has been widely used for studying genetic relationships among cultivars of different species or genera. The advantages of this technique include reproducibility, high levels of polymorphism detection, genomewide distribution of markers, and no requirement of prior knowledge of the genome being studied (Mueller and Wolfenbarger, 1999; Prabhu and Gresshof, 1994). The AFLP technique is particularly valuable for studying intraspecific variation and also plants that are polyploid (Meudt and Clarke, 2007). This technique has been successfully used for studying cultivar differences of Euphorbia pulcherrima (Parks and Moyer, 2004) and detecting sports and somaclonal variants of Syngonium podophyllum (Chen et al., 2006). AFLP has also been used successfully for studying allopolyploidy among cultivars or collections of Cucumis $\times$ hytivus (Chen et al., 2007), Gossypium spp. (Liu et al., 2001), and Triticum spp. (Ozkan et al., 2002) and autopolyploidy among Dactylorhiza spp. (Hedren et al., 2001), accessions of Solanum tuberosum (Milbourne et al., 1997; Spooner et al., 2005), and collections of Saxifraga cernua, including aneuploid lines (Kjolner et al., 2004).

This study was undertaken to analyze the genetic relationships of popular croton cultivars using the AFLP technique and determine possible factors contributing to the wide morphological variation of the cultivars.

\section{Materials and Methods}

Plant materials. A total of 44 cultivars of C. variegatum and four cultivars of Acalypha wilkesiana Mull.Arg. were used in this study (Table 1). A. wilkesiana also belongs to the family Euphorbiaceae. All plants were gathered from germplasm maintained at the University of Florida's Mid-Florida Research and Education Center or were collected from ornamental foliage plant nurseries in central and southern Florida.

DNA extraction. Total DNA was extracted from newly expanding leaves of the 44 crotons and four A. wilkesiana cultivars using the cetyltrimethylammonium bromide method (Bousquet et al., 1990). DNA quality was checked by loading DNA on a $0.65 \%$ 
Table 1. Origin, source, and leaf phenotype of 44 cultivars of Codiaeum variegatum and also four cultivars of Acalypha wilkesiana used for studying their genetic relationships by amplified fragment length polymorphism markers.

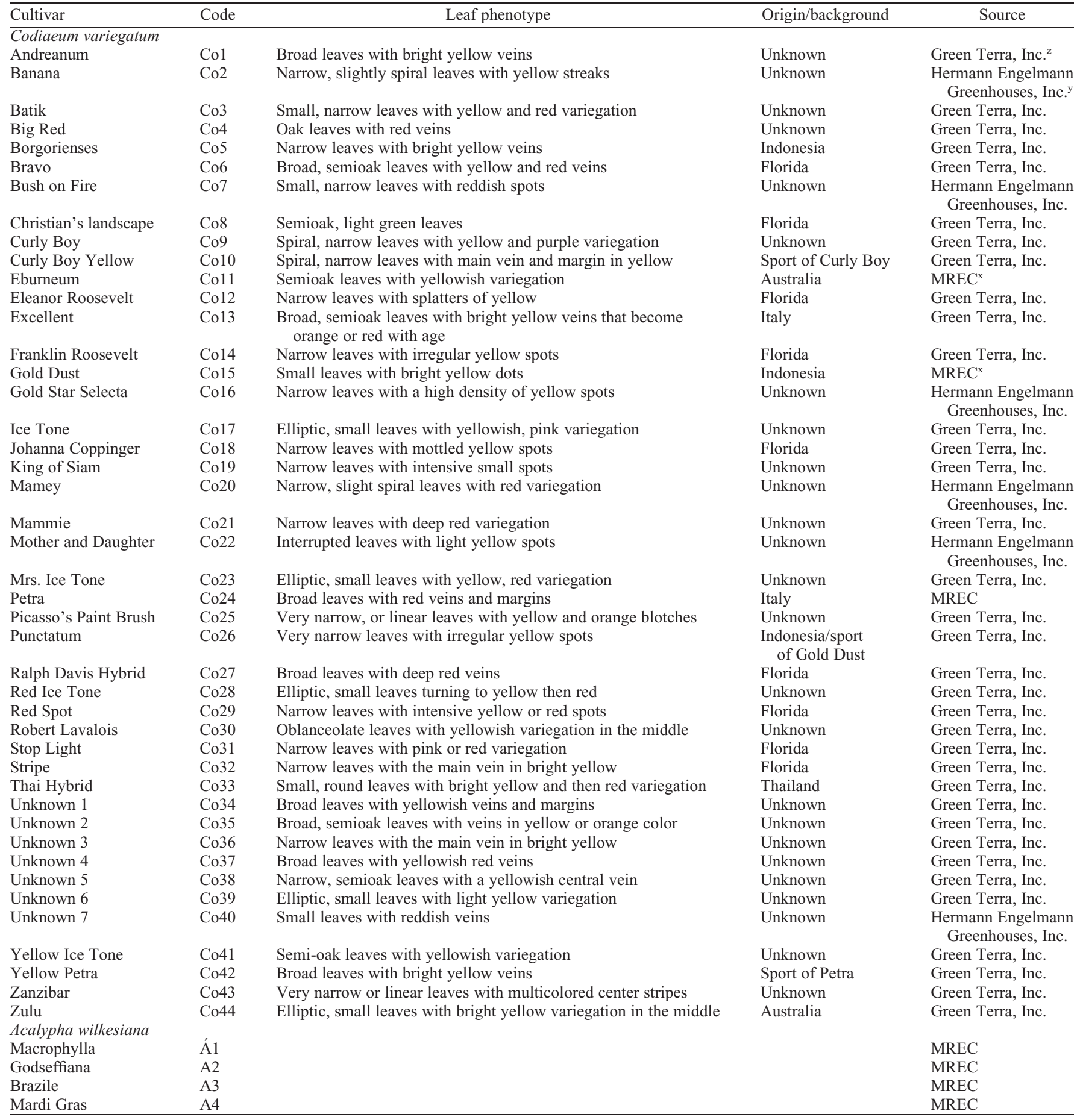

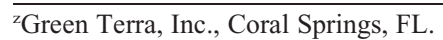

${ }^{y}$ Hermann Engelmann Greenhouses, Inc., Apopka, FL.

${ }^{x}$ University of Florida, Mid-Florida Research and Education Center, Apopka, FL.

agarose gel, and DNA concentration of each sample was measured using a TURNER Biosystems TB5-380 Fluorometer (Turner BioSystems Inc., Sunnyvale, CA).

Amplified fragment length polymorphism analysis. AFLP analysis was conducted as described by Vos et al. (1995) with minor modifications. Genomic DNA at 200 ng each was digested by $2 \mathrm{U}$ EcoRI and $2 \mathrm{U} M s e \mathrm{I}$ (New England BioLabs, Ipswich, MA) and ligated by T4 DNA ligase (Promega, Madison,
WI). A pre-amplification was performed on a DNA Engine ${ }^{\circledR}$ (Bio-Rad Laboratories, Hercules, CA) with one cycle of $94{ }^{\circ} \mathrm{C}$ for $1 \mathrm{~min}$ followed by 20 cycles of $94{ }^{\circ} \mathrm{C}$ for $30 \mathrm{~s}, 56^{\circ} \mathrm{C}$ for $1 \mathrm{~min}$, and $72{ }^{\circ} \mathrm{C}$ for $1 \mathrm{~min}$ with a final extension step at $72{ }^{\circ} \mathrm{C}$ for $10 \mathrm{~min}$.

A total of 14 EcoRI +3 and $M s e I+3$ primer pairs were used in this study (Table 2). A $12-\mu \mathrm{L}$ selective amplification solution was made including $3 \mu \mathrm{L} 10 \times$ diluted preamplification product, 0.5 U Taq DNA poly- merase (Promega), $0.25 \mathrm{~mm}$ dNTPs, $0.05 \mu \mathrm{M}$ of IRDye 700 or IRDye 800 labeled $E c o$ RI +3 primers, and $0.125 \mu \mathrm{M} \mathrm{MseI}+3$ primers. A selective amplification was performed on the DNA Engine ${ }^{\circledR}$ (Bio-Rad Laboratories, Hercules, CA) by a program of $94{ }^{\circ} \mathrm{C}$ for $2 \mathrm{~min}$, 10 cycles starting at $94^{\circ} \mathrm{C}$ for $30 \mathrm{~s}, 65^{\circ} \mathrm{C}$ for $30 \mathrm{~s}$ with a reduction in the annealing temperature of $0.7^{\circ} \mathrm{C}$ per cycle, $72{ }^{\circ} \mathrm{C}$ for $60 \mathrm{~s}$, then cycled 23 times at $94{ }^{\circ} \mathrm{C}$ for $30 \mathrm{~s}, 56{ }^{\circ} \mathrm{C}$ $30 \mathrm{~s}, 72{ }^{\circ} \mathrm{C} 60 \mathrm{~s}$, with a final extension of 
5 min at $72{ }^{\circ} \mathrm{C}$. The selectively amplified products were denatured for $3 \mathrm{~min}$ at $94{ }^{\circ} \mathrm{C}$ and electrophoresed on $25 \mathrm{~cm} \times 0.25-\mathrm{mm} 6.5 \%$ denatured polyacrylamide gel in $1 \times \mathrm{TBE}$ buffer using a LI-COR DNA Analyzer 4300 (LI-COR Biosciences, Lincoln, NE).

Data analysis. To confirm the reliability, the pre-amplification, selective amplification

Table 2. Total number of fragments, percentage of polymorphic fragments, and polymorphic information content (PIC) generated from 44 cultivars of Codiaeum variegatum using 14 amplified fragment length polymorphism primer combinations.

\begin{tabular}{lcccc}
\hline Primer combination & $\begin{array}{c}\text { Total fragments } \\
\text { (no.) }\end{array}$ & $\begin{array}{c}\text { Polymorphic } \\
\text { fragments (no.) }\end{array}$ & $\begin{array}{c}\text { Proportion of } \\
\text { polymorphic } \\
\text { fragments (\%) }\end{array}$ & $\begin{array}{c}\text { Polymorphic } \\
\text { information } \\
\text { content (PIC) }\end{array}$ \\
\hline E-ACC + M-CAA & 27 & 20 & 74.1 & 0.20 \\
E-AGG + M-CAA & 12 & 9 & 75.0 & 0.25 \\
E-AAG + M-CAC & 43 & 33 & 76.7 & 0.15 \\
E-AGC + M-CAC & 60 & 52 & 86.7 & 0.25 \\
E-ACA + M-CAG & 26 & 15 & 57.7 & 0.16 \\
E-ACG + M-CAG & 33 & 29 & 87.9 & 0.27 \\
E-AAC + M-CAT & 31 & 21 & 67.7 & 0.22 \\
E-ACT+ M-CAT & 28 & 25 & 89.3 & 0.20 \\
E-ACA + M-CTA & 51 & 45 & 88.2 & 0.19 \\
E-ACT+ M-CTA & 42 & 34 & 81.0 & 0.26 \\
E-ACA + M-CTG & 56 & 48 & 85.7 & 0.26 \\
E-ACT + M-CTG & 54 & 51 & 94.4 & 0.15 \\
E-AAG + M-CTT & 38 & 23 & 60.5 & 0.20 \\
E-ACG + M-CTT & 48 & 39 & 81.3 & -15 \\
Total & 549 & 444 & 80.9 & 0.22 \\
Mean & 39.2 & 31.7 & & \\
\hline
\end{tabular}

${ }^{\mathrm{z}} \mathrm{PIC}=1-\Sigma \mathrm{P}_{\mathrm{ij}}$, in which $\mathrm{P}_{\mathrm{ij}}$ is the frequency of the $j^{\text {th }}$ allele for the $i^{\text {th }}$ locus.

and gel electrophoresis were conduced twice for the DNA extracted from the cultivars listed in Table 1. AFLP fragments were scored visually and analyzed using Saga software (LICOR Biosciences). The average polymorphic information content (PIC) for croton cultivars was calculated using the formula given by Powell et al. (1996) and Smith et al. (1997): PIC $=1-\Sigma \mathrm{P}^{2}{ }_{\mathrm{ij}}$, in which $\mathrm{P}_{\mathrm{ij}}$ is the frequency of the $j^{\text {th }}$ allele for the $i^{\text {th }}$ locus. Genetic distances among the cultivars were calculated using the mean character difference (number of variable positions divided by number of nucleotides compared); both phylogram and cladogram were constructed according to the neighbor-joining method using PAUP* (Phylogenetic Analysis Using Parsimony) Version 4.0b10 (Swofford, 2002). Cultivars of A. wilkesiana 'Macrophylla' were used as an outgroup to root the tree. The phylogram showed the genetic relationships of cultivars based on the cluster pattern and genetic distance; the genetic distance was represented by branch length. Because some of the branches were very short, the topology of the tree could not be well illustrated using the phylogram. Thus, the cladogram was developed, which showed

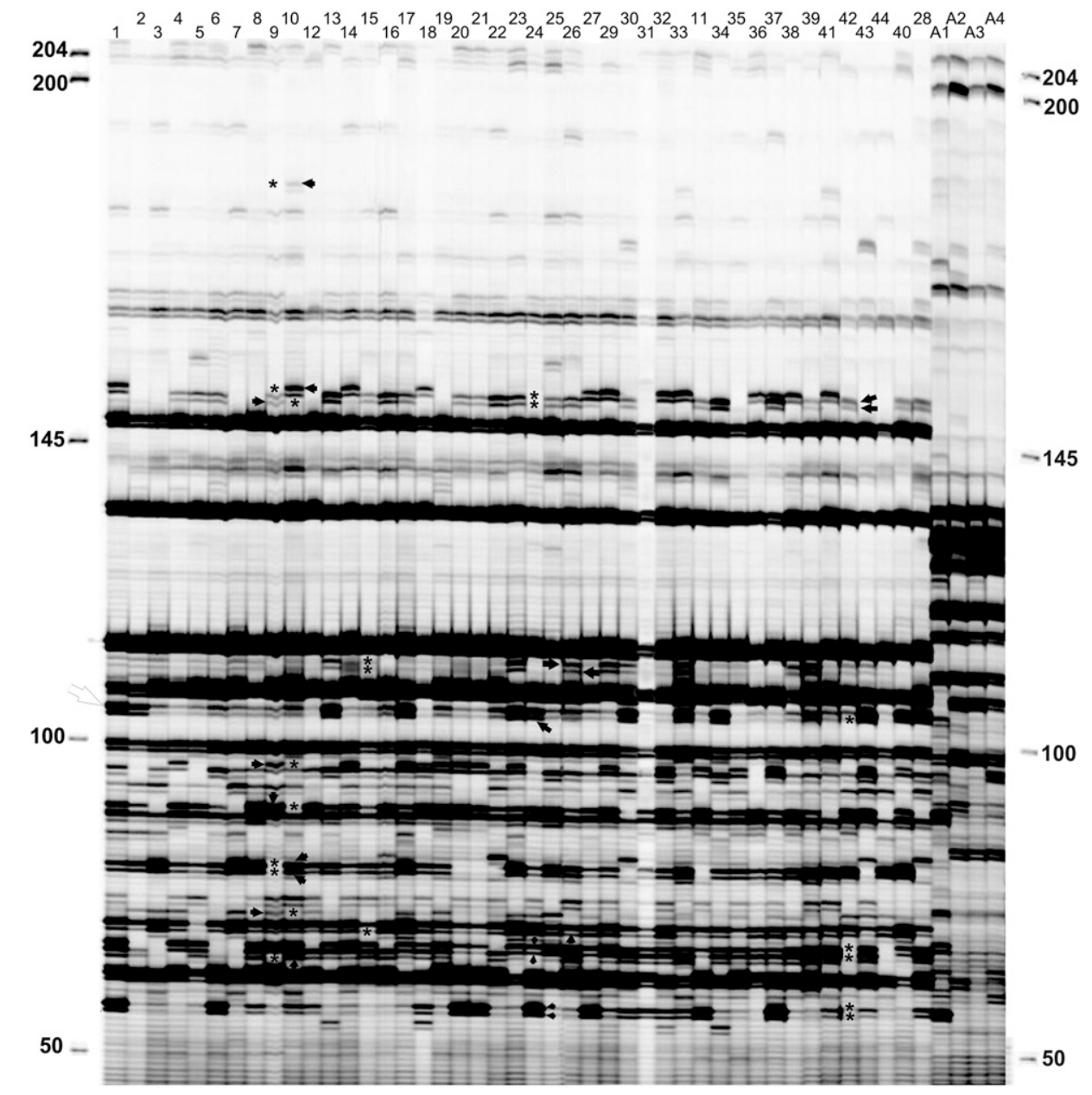

Fig. 1. Amplified fragment length polymorphism pattern generated by primer set E-AGC and M-CAC for the 44 cultivars of Codiaeum variegatum. Arrows point to gained and $\star$ indicates lost fragments for the parental and sport pair of 'Curly Boy' (Co9) with 'Curly Boy Yellow' (Co10), 'Gold Dust' (Co15) with 'Punctatum' (Co26), and 'Petra' (Co24) with 'Yellow Petra' (Co42). The numbers on the top of gel image representing cultivars, which were the same numbers as those codes in Table 1. Some of the numbers, however, do not follow numerical order. 


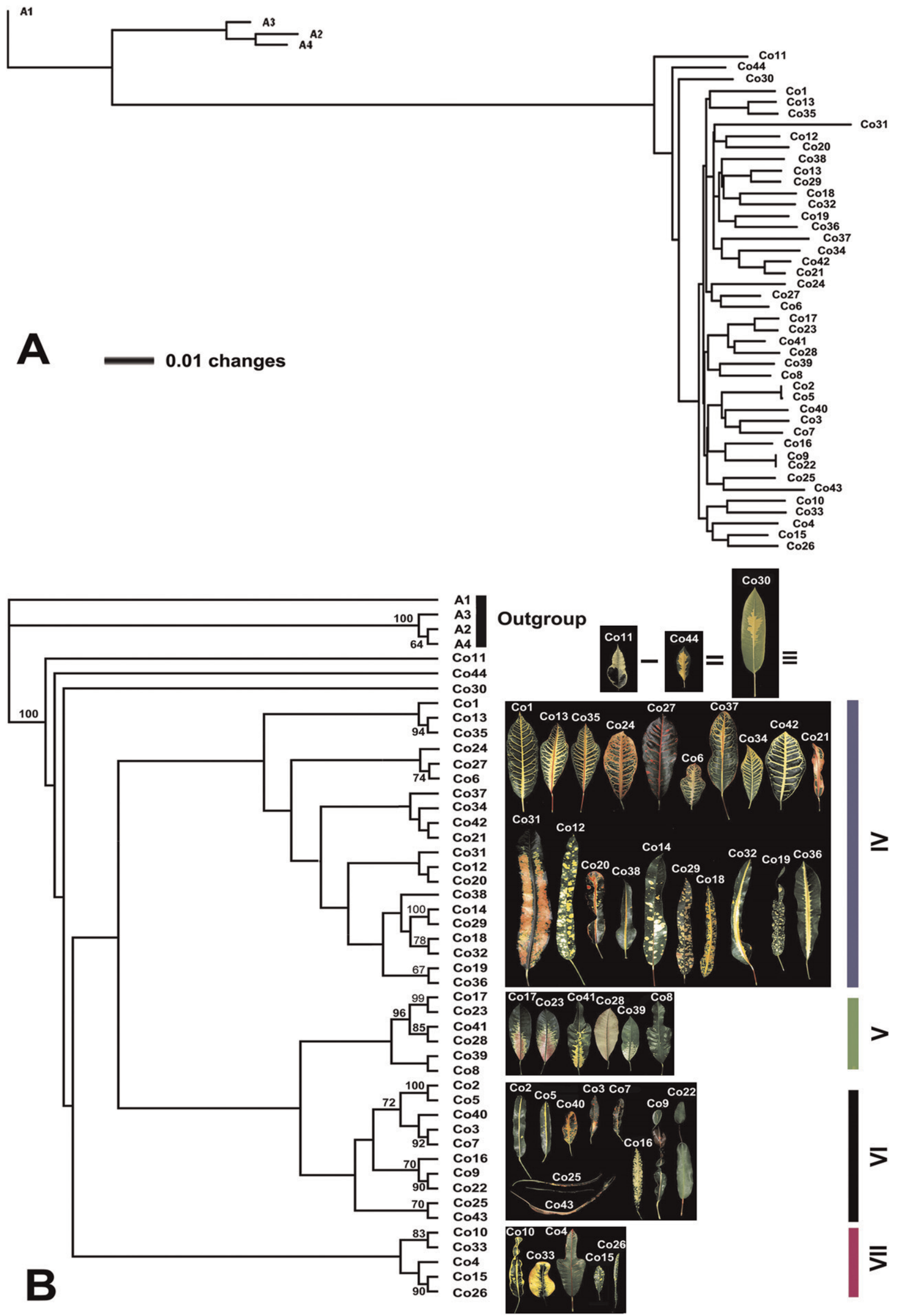


the genetic relationships based on cluster pattern. The branch robustness of the tree was evaluated by the bootstrap method using PAUP * 4.0b10 (Swofford, 2002) with 10,000 replicates.

\section{Results}

Variation in amplified fragment length polymorphism markers. The 14 primer sets generated clearcut AFLP profiles for the 44 croton cultivars and four cultivars of $A$. wilkesiana. An example of the AFLP profiles using E-AGC + M-CAC primer is shown in Figure 1. A total of 549 AFLP fragments were produced from the 44 croton cultivars by the 14 primer combinations, of which 444 $(81 \%)$ were polymorphic (Table 2$)$. Fragments ranged from $50 \mathrm{bp}$ to $500 \mathrm{bp}$ with a majority being distributed between $80 \mathrm{bp}$ and $350 \mathrm{bp}$. The number of polymorphic fragments of crotons per AFLP primer combination varied from nine to 52 with an average of 32. The PIC values of the crotons ranged from 0.15 to 0.29 (Table 2).

Genetic relationships of cultivars. The Acalypha cultivars had genetic distances of 0.48 to 0.58 away from the croton cultivars and thus were positioned outside of the Codiaeum cluster (Fig. 2A-B). The 44 croton cultivars divided into seven clusters (Fig. 2B), of which 19 nodes were supported by bootstrap values 64 or greater. The monophyletic status of 44 croton cultivars was supported by the bootstrap value of $100 \%$. However, within croton cultivar clades, most of the bootstrap values are presented at the terminal of the branches.

Cluster I contained a single cultivar, Eburneum (Co11), with semioak leaves and light yellow variegation. Cluster II had only 'Zulu' (Co44) showing small, elliptic leaves with bright yellow variegation in the center. Cluster III contained only 'Robert Lavalois' (Co30), which has oblanceolate leaves and yellowish variegation in the middle. Genetic distances among these three cultivars ranged from 0.188 to 0.217 , and their distance from the rest of croton cultivars was 0.322 .

Cluster IV held 20 cultivars with genetic distance among them ranging from 0.086 to 0.275 . All cultivars in Cluster IV had large leaves (leaf blade greater than $15 \mathrm{~cm}$ long), and nine of these have broad leaves. 'Andreanum' $(\mathrm{Co} 1)$ is a popular cultivar with leaf blades $25 \mathrm{~cm}$ in length. 'Excellent' (Co13) and 'Petra' (Co24) were selections from the breeding program of the Azienda Floreale Diem Nursery in Italy in the 1970s (Brown, 1995). The cultivar name of Co35 is unknown; it could be closely related to 'Excel- lent' because their genetic distance was only 0.089 and morphologically both have semioaked leaves and bold yellow veins (Fig. 2B). 'Ralph Davis Hybrid'(Co27) is one in a series of croton hybrids developed in the 1920s and 1930s by Ralph Davis, a well-known croton breeder in North Miami Beach, FL (Brown, 1995). 'Bravo' (Co6) was released by $\mathrm{Al}$ Cutler, another breeder in Miami, FL, in the 1920s. Co37 and Co34 are two cultivars without names. Co42 is 'Yellow Petra', a sport selected from 'Petra'.

Eleven of the 20 cultivars in Cluster IV had large but narrow leaves. Co21 is the cultivar Mammie (Co21). Stoplight (Co31) is a hybrid developed by Charles Rutherford, Miami, FL, in the 1930s (Brown, 1995). 'Eleanor Roosevelt' (Co12), 'Franklin Roosevelt' (Co14), 'Johanna Coppinger' (Co18), and 'Stripe' (Co32) were released by breeder Henry Coppinger in Miami, FL, from the 1920 s to the 1930s. Co20 is the cultivar Mamey and $\mathrm{Co38}$ is a cultivar without a name. 'Red Spot' (Co29) has similar leaf morphology to 'Franklin Roosevelt' but with a higher density of yellow spotting. 'King of Siam' (Co19) is closely related to Co36 without a name; their genetic distance was 0.163 .

Cluster V had six cultivars; the genetic distance among the cultivars ranged from 0.071 to 0.255 . All showed small, elliptic leaf morphology except for cultivar Christian's Landscape $(\mathrm{Co} 8)$ that had oak leaves. 'Christian's Landscape' is a hybrid developed by Aubrey Christian, one of the first Florida croton breeders in Miami (Brown, 1995). Co8 and unnamed cultivar Co39 were close with a genetic distance of 0.17.

There were 10 cultivars with five different leaf morphology types in Cluster VI. Leaves in this cluster include narrow, spiral, interrupted, or linear. The genetic distance among the cultivars varied from 0.002 to 0.288 . 'Banana' (Co2), 'Batik' (Co3), 'Bogorienses' (Co5), 'Bush on Fire' (Co7), and 'Gold Star Selecta' (Co16) had narrow leaves (Table 1; Fig. 2B). 'Bogorienses' was named for the Bogor Garden, Indonesia (Brown, 1995). 'Curly Boy' (Co9) has spiral leaves. Co40 has no name. 'Mother and Daughter' (Co22), an interrupted leaf form, was named because of a small leaf sprouting from the top of the bigger leaf joined by the slender midvein. Also within this cluster, 'Picasso's Paint Brush' (Co25) and 'Zanzibar' (Co43) were positioned together and show multicolored linear leaves (Fig. 2B).

Five cultivars situated in Cluster VII have five leaf morphologies, respectively, including spiral (Co10), round (Co33), oak (Co4), small (Co15), and narrow to linear (Co26).
The genetic distance among these cultivars ranged from 0.128 to 0.255 .

\section{Discussion}

Genetic relationships of the 44 croton cultivars. The present study based on AFLP markers differentiated 44 cultivars and grouped them in a dendrogram with seven clusters. These established genetic relationships concurred with the history of croton introduction, adaptation, geographical isolation, and breeding activities but differed from the classification made by the Croton Society (2010) based on leaf morphology. These results were in contrast to cytological analyses (Chennaveeraiah and Wagley, 1985; Deng et al., 2010; Pancho and Hilario, 1963; Sharma and Bal, 1958) in which no relationships among cultivars or between chromosome numbers and cultivar morphology were established.

Three cultivars in Clusters I, II, and III, respectively, represent early introductions to Australia or selections from the early introduction such as 'Eburneum' (Brown, 1995) and 'Zulu' (Spink, 2001). Adaptation and geographical isolation may have resulted in a greater genetic difference from the other cultivars. Thus, they were positioned outside of the other croton clusters in the dendrogram (Fig. 2).

Cultivars situated in Cluster IV are mainly of hybrid origin. Among the 20 cultivars, two are hybrids from the Azienda Floreale Diem Nursery in Italy. The rest are largely Florida hybrids with a compact growth form and large leaf size regardless of leaf shape and variegation patterns. These hybrids were developed by eight croton aficionados: Aubrey Christian, Henry Coppinger, Charles Rutherford, Rudy Bachmann, Al Culter, Ralph Davis, and Richard Krukonis, all of Miami, and Robert Halgrim, of Fort Myers, FL, in the 1920 s and 1930s. Their goals for croton improvement were to increase leaf sizes, intensify foliar colors, and select compact growth forms (Brown, 1995). Because all the genetic resources in the United States were initially introduced from Europe in 1871, it is not surprising that cultivars developed in Italy were positioned in the same cluster with the Florida hybrids.

Cultivars in Cluster V have small, elliptic leaves except 'Christian's Landscape' (Co8) and 'Yellow Ice Tone' that have semioaked leaves. The names of 'Ice Tone' (Co17), 'Mrs. Ice Tone' (Co23), 'Yellow Ice Tone' (Co41), and 'Red Ice Tone' (Co28) and their close positioning within the dendrogram suggest that they may have been developed

Fig. 2. Dendrogram of the 44 Codiaeum variegatum cultivars and four Acalypha wilkesiana cultivars. (A) Phylogram of 44 C. variegatum cultivars analyzed based on the mean character difference of amplified fragment length polymorphism data using neighbor-joining method. A. wilkesiana 'Macrophylla' (A1) was used as an outgroup to root the tree. (B) Cladogram of the phylogenetic tree. The number above the branches or before slash indicates proportion of 10,000 nonparametric bootstrap support calculated by PAUP* versus $4.0 \mathrm{~b} 10$ (Swofford, 2002). The 44 croton cultivars were divided into seven clusters. Clusters I, II, and III had one cultivar each, representing those cultivated in Australia. Cluster IV had 20, large-leaved cultivars that were primarily hybrids developed in Florida in the 1920s and 1930s and some from Europe in the 1970s. There were six cultivars in Cluster V, which were related to 'Ice Ton', a cultivar with thin and elliptic leaves. Cluster VI contained 10 cultivars that have narrow and small, linear, spiral, or interrupted leaves. Five cultivars were positioned in Cluster VII; they have either small leaves or a compact growth style and are probably native to Southeast Asia. 
by a single breeder, although the historical record has been lost. Because 'Christian's Landscape' (Co8) was also positioned in this cluster, this group of cultivars may be related to cultivars released by Aubrey Christian.

Cultivars in Cluster VI were those with linear, narrow, interrupted, or spiral leaves. At present, it is unclear why cultivars with the unique shaped leaves were positioned together. Cultivars from Cluster VII were closely related to those cultivars from Southeast Asia, which include 'Gold Dust' (Co15) and 'Punctatum' (Co26). In contrast to breeding activities in Europe and Florida, breeding in Thailand was focused on developing smaller plant types with radically different leaf shapes and new, more brilliant coloring such as Thai hybrid (Co33) (Brown, 1995).

Bootstrap analysis of the dendrogram did not support some of the main nodes of croton cultivars (Fig. 2B). The lack of bootstrap support may be attributed to the network evolutionary pattern (frequent hybridization or recent polyploidization events) and uniform genome (recent species radiation or recent genome duplication) (Felsenstin, 2004; Soltis and Soltis, 2003), which is well documented to have happened in cultivated crotons. The introduction of crotons from tropical Southeast Asia to the temperate climate of Europe represented the first wave of adaptive radiation. Breeding of new cultivars for use as containerized plants that were able to adapt to interior conditions in Europe may have resulted in further genetic changes for adaptation. Furthermore, the introduction of those hybrids from Europe to the United States, particularly south Florida, as garden plants could be another wave of adaptive radiation.

Possibility of a common progenitor. Another finding in this study is the surprisingly genetic similarity among the 44 cultivars, i.e., genetic distance among cultivars 0.322 or less. The close genetic relationships could be attributed to a possibility that cultivated Codiaeum have a common progenitor. Brown (1995) believed that the Mollucan Islands of Indonesia are the place where $C$. variegatum originated and hypothesized that the first $C$. variegatum was the wild form of $C$. 'Mollucanum'. C. 'Mollucanum' sported 'Aureo Maculatum' and 'Aureo Maculatum' sported 'Punctatum'. As indicated by Brown (1995), 'Aureo Maculatum' was actually the current cultivar Gold Dust. 'Mollucanum' was not available for this test, but 'Gold Dust' (Co15) and 'Punctatum' (Co26) were included in this study. 'Gold Dust' and 'Punctatum' were positioned together in Cluster VII (Fig. 2), which includes cultivars originating from Southeast Asia. Except for Clusters I, II, and III; Cluster VII was outside of Clusters IV, V, and VI. Additionally, the AFLP profile generated by primer set E-AGC and M-CAC showed that 'Gold Dust' and 'Punctatum' had similar fragment patterns except that 'Punctatum' had three additional fragments as illustrated in Figure 2. The genetic distance between the two was 0.128 . These results may indicate that 'Punctatum' could be indeed the sport of 'Gold Dust'. However, regarding the genetic lineage of cultivated C. variegatum, further studies for comparing the indigenous crotons of the Mollucan Islands with the current cultivars are required.

Genetic polymorphisms could be a factor contributing to the morphological diversity. Although the 44 cultivars have been shown to be genetically close, individually, they were genetically polymorphic at the DNA level. Among the 549 AFLP fragments, $81 \%$ were polymorphic (Table 2). AFLP profiles also demonstrated that different cultivars had different fragment patterns (Fig. 2). The PIC values ranged from 0.15 to 0.29 with an average of 0.22 (Table 2), which also indicates high polymorphisms. The PIC value is a way of measuring polymorphism because it provides an estimate of the discriminatory power of a marker by taking into account not only the number of alleles at a locus, but also the relative frequencies of these alleles. Because AFLP markers are codominant, a PIC value of 0.5 will be the highest score for any given fragment. The high polymorphisms at the DNA level may be related to the gain or loss of genes. For example, in addition to the parental and sport pair of 'Gold Dust' and 'Punctatum' in which there was a gain of three fragments in 'Punctatum' (Co26) compared with 'Gold Dust' (Co15) in the AFLP profile generated by primer set E-AGC and M-CAC (Fig. 2), the comparison of another parental and sport pair of 'Curly Boy' (Co9) and 'Curly Boy Yellow' (Co10) showed that five fragments were lost and three fragments were gained in 'Curly Boy' and five fragments lost and four fragment gained in 'Curly Boy Yellow'. In the pair of 'Petra' (Co24) and 'Yellow Petra' (Co42), five fragments were lost and two fragments were gained in 'Petra' and two fragments gained and five fragments lost in 'Yellow Petra'. It was not our initial intention in this study to document fragment gain and loss among cultivars. However, the obvious polymorphic fragments in connection with our studies of chromosome variation (Deng et al., 2010) suggest that in addition to chromosome variation, fragment gain or loss may also contribute to the wide phenotypic variation, particularly in leaf morphology. Chromosomal variation and instability resulting in DNA sequence gain and loss have also been documented in synthetic autopolyploid Phlox drummondii (Raina et al., 1994) and allopolyploid Brassica (Song et al., 1995) and wheat (Aegilops-Triticum) (Ozkan et al., 2001).

In conclusion, AFLP analysis effectively discriminated the 44 croton cultivars, although they are largely polyploid. Based on their genetic distance, the 44 cultivars divided into seven clusters, and their relationships concur with the history of croton geographical isolation, adaptation, introduction, and breeding activities, not with the leaf classification made by the Croton Society (2010) based on morphology alone. The established relationships will help future croton germplasm conservation and new cultivar de- velopment. The AFLP analysis also provides some evidence that cultivated crotons may share a common progenitor because they are genetically so close. Additionally, comparing the AFLP profile of three pairs of parental and sport plants showed that AFLP fragment gain or loss may also be a factor underlying the variation in plant morphology, probably the diverse leaf shapes and variegation patterns.

\section{Literature Cited}

Bousquet, J., L. Simmon, and M. Lalonde. 1990. DNA amplification from vegetative and sexual tissues of trees using polymerase chain reaction. Can. J. For. Res. 20:254-257.

Brown, B.F. 1995. A Codiaeum encyclopedia: Crotons of the world. Valkaria Tropical Garden, Valkaria, FL.

Chen, J., R.J. Henny, P.S. Devanand, and C.T. Chao. 2006. AFLP analysis of nephthytis (Syngonium podophyllum Schott) selected from somaclonal variants. Plant Cell Rep. 24:743749.

Chen, J., D.B. McConnell, D.J. Norman, and R.J. Henny. 2005. The foliage plant industry. Hort. Rev. (Amer. Soc. Hort. Sci.) 31:47-112.

Chen, J. and R.H. Stamps. 2006. Cutting propagation of foliage plants, p. 203-228. In: Dole, J.M. and J.L. Gibson (eds.). Cutting propagation: A guide to propagating and producing floriculture crops. Ball Publishing, Batavia, IL.

Chen, L., Q. Lou, Y. Zhuang, J. Chen, X. Zhang, and J.N. Wolukau. 2007. Cytological diploidization and rapid genome change of the newly synthesized allotetraploids Cucumis $\times$ hytivus. Planta 225:603-614.

Chennaveeraiah, M.S. and S.K. Wagley. 1985. Chromosome mosaicism in cultivars of garden crotons (Codiaeum variegatum). Nucleus 28 : $8-13$.

Deng, M., J. Chen, R.J. Henny, and Q. Li. 2010. Chromosome number and karyotype variation in Codiaeum variegatum cultivars. HortScience 45:538-540

Felsenstin, J. 2004. Inferring phylogenesis. Sinauer Associates, Inc., Sunderland, MA.

Govaerts, R., D.G. Frodin, and A. Radcliffe-Smith 2000. World checklist and bibliography of Euphorbiaceae 1. Royal Bot. Garden, Kew, UK.

Hedren, M., M.F. Fay, and M.W. Chase. 2001. Amplified fragment length polymorphisms (AFLP) reveal details of polyploid evolution in Dactylorhiza (Orchidaceae). Amer. J. Bot. 88:1868-1880.

Kjolner, S., S.M. Sastad, P. Taberlet, and C. Brochmann. 2004. Amplified fragment length polymorphism versus random amplified polymorphic DNA markers: Clonal diversity in Saxifraga cernua. Mol. Ecol. 13:81-86.

Liu, B., C.L. Brubaker, G. Mergeai, R.C. Cronn, and J.F. Wendel. 2001. Polyploid formation in cotton is not accompanied by rapid genomic changes. Genome 44:321-330.

Meudt, H.M. and A.C. Clarke. 2007. Almost forgotten or latest practice? AFLP applications, analysis and advances. Trends Plant Sci. 12: 106-117.

Milbourne, D., R. Meyer, D. Milbourne, R. Meyer, J.E. Bradshaw, E. Baird, N. Bonar, J. Provan, W. Powell, and R. Waugh. 1997. Comparison of PCR-based marker systems for the analysis of genetic relationships in cultivated potato. Mol. Breed. 3:127-136

Mueller, U.G. and L.L. Wolfenbarger. 1999. AFLP genotyping and fingerprinting. Trends Ecol. Evol. 14:389-394. 
Ogunwenmo, K.O., O.A. Idowu, C. Innocent, E.B. Esan, and O.A. Oyelana. 2007. Cultivars of Codiaeum variegatum (L.) Blume (Euphorbiaceae) show variability in phytochemical and cytological characteristics. Afr. J. Biotechnol. 6:2400-2405.

Ozkan, H., A. Brandolini, R. Schafer-Pregl, and F. Salamini. 2002. AFLP analysis of a collection of tetraploid wheats indicates the origin of emmer and hard wheat domestication in Southern Turkey. Mol. Biol. Evol. 19:1797-1801.

Ozkan, H., A.A. Levy, and M. Feldman. 2001. Allopolyploidy-induced rapid genome evolution in the wheat (Aegilops-Triticum) group. Plant Cell 13:1735-1747.

Pancho, J.V. and F. Hilario. 1963. Chromosome numbers and intraspecific hybridization in croton (Codiaeum variegatum Blume). Philippine Agric. 47:104-112.

Parks, E.J. and J.W. Moyer. 2004. Evaluation of AFLP in poinsettia: Polymorphism selection, analysis, and cultivar identification. J. Amer. Soc. Hort. Sci. 129:863-869.

Powell, W., G.C. Machray, and J. Provan. 1996. Polymorphism revealed by simple sequence repeats. Trends Plant Sci. 1:215-222.
Prabhu, R.R. and P.M. Gresshof. 1994. Inheritance of polymorphic markers generated by DNA amplification fingerprinting and their use as genetic markers in soybean. Plant Mol. Biol. 26:105-116.

Raina, S.N., A. Parida, K.K. Koul, S.S. Salimath, M.S. Bisht, V. Raja, and T.N. Khoshoo. 1994. Associated DNA changes in polyploids. Genome 37:560-564.

Sharma, A.K. and A.K. Bal. 1958. A cytological study on the different varieties of Codiaeum variegatum $\mathrm{BL}$. as means of finding out the mechanism of their evolution. Nucleus 1:223266.

Smith, J.S.C., E.C.L. Chin, H. Shu, O.S. Smith, S.J. Wall, M.L. Senior, S.E. Mitchell, S. Kresovich, and J. Ziegle. 1997. An evaluation of the utility of SSR loci as molecular markers in maize (Zea mays L.): Comparison with data from RFLPs and pedigree. Theor. Appl. Genet. 95:163-173.

Soltis, P.S. and D.E. Soltis. 2003. Applying the bootstrap in phylogeny reconstruction. Stat. Sci. 18:256-267.

Song, K., P. Liu, K. Tang, and T.C. Osborne. 1995. Rapid genome change in synthetic polyploids of Brassica and its implications for polyploid evolution. Proc. Natl. Acad. Sci. USA 92: 7719-7723.

Spink, G. 2001. Codiaeum plant named 'Croton Zulu'. 25 Mar. 2009. <http://patft.uspto.gov/ netacgi/nph-Parser?Sect $1=$ PTO2\&Sect $2=$ HITOFF \& $\mathrm{p}=1 \& \mathrm{u}=\% 2$ Fnetahtm $\% 2$ FPTO $\%$ 2Fsearch-bool.html\&r=4\&f=G\&l=50\&col= AND\&d=PTXT\&s $1=$ codiaeum $\& O S=$ codiaeum $\&$ $\mathrm{RS}=$ codiaeum $>$.

Spooner, D.M., K. Mclean, G. Ramsay, R. Waugh, and G. Bryan. 2005. A single domestication for potato based on multilocus amplified fragment length polymorphism genotyping. Proc. Natl. Acad. Sci. USA 102:14694-14699.

Swofford, D.L. 2002. PAUP*. Phylogenetic Analysis Using Parsimony (*and other methods). Version 4.0b10. Sinauer Associates, Sunderland, MA.

The Croton Society. 2010. Croton information: Major leaf types. 16 Apr. 2010. <http://www.crotons. org $>$.

Vos, P.R., M. Hogers, M. Bleeker, T. van de Lee Reijans, M. Hornes, A. Frijters, J. Pot, J. Peleman, M. Kuiper, and M. Zabeau. 1995. AFLP: A new technique for DNA fingerprinting. Nucleic Acids Res. 23:4407-4414. 